\title{
Evaluation of four protein extraction methods for proteomic analysis of mango peel
}

\author{
D.J. Liao ${ }^{1 *}$, X.P. Lu ${ }^{1 *}$, H.S. Chen ${ }^{1}$, Y. $\mathrm{Lu}^{2}$ and Z.Y. Mo ${ }^{1}$ \\ ${ }^{1}$ State Key Laboratory of Respiratory Disease, \\ Guangzhou Institute of Respiratory Disease, \\ The First Affiliated Hospital of Guangzhou Medical University, Guangzhou, \\ China \\ ${ }^{2}$ Chinese Academy of Tropical Agricultural Sciences Environment and Plant \\ Protection Institute, Danzhou, China \\ *These authors contributed equally to this study. \\ Corresponding author: Z.Y. Mo \\ E-mail:moziyao@gird.cn
}

Genet. Mol. Res. 15 (3): gmr.15039006

Received July, 21, 2016

Accepted August 1, 2016

Published August 30, 2016

DOI http://dx.doi.org/10.4238/gmr.15039006

Copyright $(2016$ The Authors. This is an open-access article distributed under the terms of the Creative Commons Attribution ShareAlike (CC BY-SA) 4.0 License.

\begin{abstract}
The peel of mango (Mangifera indica L.) is a special plant tissue that contains many compounds that interfere with protein extraction. A successful separation with Two-dimensional electrophoresis (2-DE) is the key step for proteomic analysis. To evaluate the efficiencies of mango peel protein extraction for 2-DE, four extraction methods were tested: 1) 2-D clean-up kit, 2) trichloroacetic acid/acetone precipitation, 3) phenol extraction, 4) phenol with methanol/ammonium acetate precipitation. The results showed that the phenol with methanol/ammonium acetate precipitation produced the best quality protein extraction and separation. Proteins were separated in 30-70 and $>70 \mathrm{kDa}$ ranges better than with the other methods. Acidic proteins had better resolution with fewer horizontal and vertical streaks.
\end{abstract}

Genetics and Molecular Research 15 (3): gmr.15039006 
Sixteen proteins were identified by maxtrix-assisted laser desorption/ ionisation time-of-flight tandem mass spectrometry (MALDI-TOF/ TOF-MS/MS). The result demonstrated that each of these four methods can be used to prepare mango peel proteins. The phenol with methanol/ ammonium acetate precipitation was the best choice for proteomic analysis of mango peel.

Key words: Mango peel; Protein extraction; 2-DE; Proteomic analysis; Evaluation

\section{INTRODUCTION}

Two-dimensional electrophoresis (2-DE) is a powerful technique for proteome analysis. Accurate proteomic results depend on good protein separation, a critical step in 2-DE (Wang et al., 2008). Plant protein extraction is challenging because certain pigments (chlorophyll, anthocyanin), polysaccharides, phenolic compounds, and organic acids are enriched in the cell walls (Schieber et al., 2003; Hirano et al., 2004; Ajila et al., 2007). It is necessary to remove these interfering compounds for successful protein separation before 2-DE. Several different protein extraction methods, have been applied in the study of genetic breeding (Tanaka et al., 2006), plant diseases (Al-Obaidi et al., 2014), insect repellants (Kim et al., 2008), and plant stress response (Xu et al., 2010) as so on. However, it is necessary to choose a suitable method for specific plant samples.

Mango (Mangifera indica L.) is an important fruit in the tropics. It is nutrient-rich and delicious, enjoying a reputation as the "king of tropical fruits". Unfortunately, mangoes are highly perishable and difficult to store because the peels are susceptible to infection by anthracnose, resulting in severe economic losses (Lima et al., 2013). This persistent blight is likely affected by the proteins in the skin that play a major role in both biotic and abiotic stresses, such as wounding and pathogens. A proteomic study of mango peel would provide an understanding of the proteins involved, and contribute to the foundation of the improvement of mangoes, as well as the prevention and control of anthracnose disease. However, mango peels are rich in ketones, polysaccharides, small molecular phenols, anthocyanins, and pectin, all of which can interfere with protein separation (Berardini et al., 2005). To date, few studies have focused on mango peel proteomics, underlining the requirement for an effective and reliable method for mango peel protein extraction.

In this study, four protocols were used to extract mango peel proteins. We identified the most suitable method for use in future studies by comparing the proteins separated by 2-DE. Selected spots were analyzed by mass spectrometry for identification.

\section{MATERIAL AND METHODS}

\section{Plant material}

Fresh, ripe mangoes of the disease-resistant strain Mangifera indica L. cultivarietas Tainong No. 1 were provided by the Environmental and Plant Protection Institute, Danzhou, China. Take $1 \mathrm{~g}$ mango peel grounding into powder in liquid nitrogen.

Genetics and Molecular Research 15 (3): gmr.15039006 


\section{Protein extraction}

\section{2-D clean-up kit treatment}

The powdered samples were suspended in lysis buffer ( $7 \mathrm{M}$ urea, $2 \mathrm{M}$ thiourea, 65 $\mathrm{mM}$ dithiothreitol (DTT), 4\% 3-[(3-Cholamidopropyl) dimethylammonio]propanesulfonate (CHAPS) (w/v), $20 \mathrm{mM}$ Tris, $1 \%$ ampholyte $(\mathrm{v} / \mathrm{v}))$ and vortexed for $10 \mathrm{~min}$ at $4^{\circ} \mathrm{C}$. The supernatant was collected after centrifugation at $15,000 \mathrm{~g}$ for $30 \mathrm{~min}$ at $4^{\circ} \mathrm{C}$, and treated according to the 2-D clean-up kit manufacturer instruction (GE Healthcare, Sweden). The pellet was dissolved in lysis buffer and centrifuged at $15,000 \mathrm{~g}$ for $1 \mathrm{~h}$ at $4^{\circ} \mathrm{C}$. The supernatant was aliquoted to new tubes and stored at $-80^{\circ} \mathrm{C}$.

\section{Trichloroacetic acid (TCA)/acetone precipitation}

The protocol was performed according to Cascardo (Cascardo et al., 2001) with some modifications. The sample was added to ice-cold acetone containing $10 \%$ TCA (w/v), 0.07\% $\beta$-mercaptoethanol $(\mathrm{v} / \mathrm{v})$ and homogenized on the ice. After precipitation $2 \mathrm{~h}$ at $-20^{\circ} \mathrm{C}$, the mixture was centrifuged at $15,000 \mathrm{~g}$ for $30 \mathrm{~min}$ at $4^{\circ} \mathrm{C}$. The supernatant was discarded, and then the pellet was rinsed three times with ice-cold extraction buffer and centrifuged at 15,000 $g$ for $30 \mathrm{~min}$ at $4^{\circ} \mathrm{C}$. The sample was precipitated for $2 \mathrm{~h}$ at $-20^{\circ} \mathrm{C}$ between each rinse. The pellet obtained after centrifugation was treated in the same way as in 2-D clean-up kit method.

\section{Phenol extraction method}

The protocol was treated according to Natarajan (Natarajan et al., 2005) with some modifications. The powdered sample was suspended in extraction buffer $[500 \mathrm{mM}$ Tris- $\mathrm{HCl}$, $\mathrm{pH}$ 7.8, $50 \mathrm{mM}$ Ethylenediaminetetraacetic acid (EDTA), $2 \mathrm{mM}$ phenylmethanesulfonyl fluoride (PMSF), $2 \% \beta$-mercaptoethanol $(\mathrm{v} / \mathrm{v})]$ and homogenized at $4{ }^{\circ} \mathrm{C}$. The same volumes of prechilled Tris-buffered phenol, $\mathrm{pH} 7.8$, was added and vortexed for $10 \mathrm{~min}$ at $4^{\circ} \mathrm{C}$ and centrifuged at $10,000 \mathrm{~g}$ for $30 \mathrm{~min}$ at $4^{\circ} \mathrm{C}$. The phenolic phase was collected and re-extracted with four volumes of prechilled methanol $2 \mathrm{~h}$ at $-20^{\circ} \mathrm{C}$. After centrifugation at $10,000 \mathrm{~g}$ for $15 \mathrm{~min}$ at $4^{\circ} \mathrm{C}$, the pellet was rinsed three times with prechilled methanol. The pellet obtained after centrifugation was treated in the same way as in 2-D clean-up kit method.

\section{Phenol with methanol/ammonium acetate precipitation}

The protocol was performed according to Carpentier (Carpentier et al., 2005) with some modifications. The powdered sample was added to ice-cold extraction buffer $(50 \mathrm{mM}$ Tris- $\mathrm{HCl}$, pH 7.5, 5 mM EDTA, $100 \mathrm{mM} \mathrm{KCl,} \mathrm{1 \%} \mathrm{DTT} \mathrm{(w/v),} \mathrm{30 \%} \mathrm{sucrose} \mathrm{(w/v),} 1 \mathrm{mM} \mathrm{PMSF).} \mathrm{The}$ mixture was homogenized and added to an equal volume of prechilled Tris-buffered phenol, $\mathrm{pH}$ 7.8. After centrifuging at $10,000 \mathrm{~g}$ for $15 \mathrm{~min}$ at $4^{\circ} \mathrm{C}$, the phenolic phase was collected and re-extracted with an aqueous extraction buffer. The sample was precipitated for $2 \mathrm{~h}$ with five volumes of $100 \mathrm{mM}$ ammonium acetate in methanol at $-20^{\circ} \mathrm{C}$. After centrifugation at $15,000 \mathrm{~g}$ for $30 \mathrm{~min}$ at $4^{\circ} \mathrm{C}$, the supernatant was removed and the pellet was rinsed twice with prechilled acetone containing $0.2 \%$ DTT $(\mathrm{w} / \mathrm{v})$, and incubated for $2 \mathrm{~h}$ at $-20^{\circ} \mathrm{C}$ for each rising step. The pellet carried out after centrifugation was treated in the same way as in 2-D clean-up kit method.

Genetics and Molecular Research 15 (3): gmr.15039006 
The protein concentrations were quantified using the Bio-Rad Protein Assay according to the Bio-Rad manufacturer instructions.

\section{Two-dimensional electrophoresis (2-DE)}

2-DE was carried out according to the Bio-Rad instrument-operating manual. The sample protein $(190 \mu \mathrm{g})$ was diluted with rehydration buffer [7 M urea, $2 \mathrm{M}$ thiourea, $65 \mathrm{mM}$ DTT, 4\% CHAPS, $0.5 \%$ ampholyte (v/v), $0.002 \%$ bromophenol blue $(\mathrm{w} / \mathrm{v})]$ and rehydrated overnight into immobilized $\mathrm{pH}$ gradient (IPG) strips with $17 \mathrm{~cm}, \mathrm{pH}$ 5-8 (Bio-Rad). The isoelectric focusing (IEF) was performed in the PROTEAN IEF Cell (BioRad) according to the manufacturer instruction (2-DE manual, Bio-Rad). After IEF, the IPG strips were equilibrated in equilibration buffer [6 M urea, 20\% glycerol (v/v), 2\% sodium dodecyl sulfate (SDS, w/v), $50 \mathrm{mM}$ Tris, $\mathrm{pH} 8.8$ ] containing $2 \%$ DTT (w/v) for $15 \mathrm{~min}$, and subsequently in equilibration buffer containing $2.5 \%$ iodoacetamide $(\mathrm{w} / \mathrm{v})$ for $15 \mathrm{~min}$. The second dimension separation was performed on the PROTEAN II xi Cell (BioRad) with 12\% SDS polyacrylamide gels: $15 \mathrm{~mA}$ per gel for $30 \mathrm{~min}, 25 \mathrm{~mA}$ per gel for $7.5 \mathrm{~h}$. The gels were stained with a Silver Stain Plus Kit (Bio-Rad) and scanned. All the 2-DE gels were repeated for three times, and analyzed by the Image Master 2-D Platinum software (version 5.0, GE Biosciences).

\section{Gel trypsin digestion}

The protein spots were cutted, destained $(15 \mathrm{mM}$ potassium ferricyanide and $50 \mathrm{mM}$ sodium thiosulfate in a 1:1 ratio), dehydrate (acetonitrile), re-dissolved (25 $\mathrm{mM}$ ammonium bicarbonate, $\mathrm{pH} 8.0$ ), re-dehydrate (acetonitrile) and digested with $10 \mu \mathrm{g} / \mathrm{mL}$ trypsin in $25 \mathrm{mM}$ ammonium bicarbonate, $\mathrm{pH} 8.0$ overnight at $37^{\circ} \mathrm{C}$ (Wang et al., 2006). The resulting peptides were extracted with $2.5 \%$ trifluoroacetic acid (TFA) in $67 \%$ acetonitrile (v/v) with 20 min sonication, evaporated in a speedvac and then dissolved with $0.1 \%$ TFA in $30 \%$ acetonitrile (v/v).

\section{Mass spectrometry analysis}

The peptides were mixed with $5 \mathrm{mg} / \mathrm{ml}$ a-ciano-4-hydroxycinnamic acid in $0.1 \%$ TFA $/ 50 \%$ acetonitrile $(\mathrm{v} / \mathrm{v})$. The mixture was deposited onto a target plate and analyzed using the 4800 plus MALDI-TOF/TOF-MS/MS Analyzer (Applied Biosystems, USA). A peptide mass fingerprinting (PMF) was acquired in reflector mode from a mass range of 900-4000 Da. The mass spectra (MS) analysis acquired were then subjected to MS/MS analysis. The MS and MS/ MS data were searched against the NCBI database, and using the MASCOT software (Matrix Science, UK). Proteins with a score above the threshold $(\mathrm{P}<0.05)$ were considered positive.

\section{RESULTS}

\section{Quantification of mango peel protein obtained from four different methods}

From our analysis, 2-D clean-up kit method yielded the highest protein $(0.695 \pm 0.12$ $\mathrm{g} / \mathrm{kg})$, followed by TCA/acetone method $(0.594 \pm 0.13 \mathrm{~g} / \mathrm{kg})$, phenol extraction method $(0.571$ $\pm 0.09 \mathrm{~g} / \mathrm{kg})$, and phenol with methanol/ammonium precipitation method $(0.557 \pm 0.11 \mathrm{~g} / \mathrm{kg})$. However, 2-DE results showed that the proteins extracted with the other three methods better 
results than 2-D clean-up kit method. Efficient and better gel separation depends on the quality of extracted proteins rather than the amount (Ashoub et al., 2011).

\section{Evaluation of the four methods by the 2-DE images}

The protein samples were separated by 2-DE gels. After visualization with silver staining, we observed good separation of proteins prepared from the four methods (Figure 1). The results from phenol-based protocols had better resolution with fewer smears and streaks and less background than the TCA/acetone and 2-D clean-up methods. The best gel image was achieved by using the phenol with methanol/ammonium precipitation. The use of phenol has been shown to decrease the interference in precipitation of the proteins by other compounds in the plant samples (Rose et al., 2004; Méchin et al., 2007). Total spot numbers from the 2-D clean-up kit, TCA/acetone, phenol extraction and phenol with methanol/ammonium precipitation were $913 \pm 24,957 \pm 40,1198 \pm 17$, and $1270 \pm 12$, respectively (Figure 2A). A greater number of spots were detected by the method of the 2-D clean-up kit and TCA/ acetone at a range of $<30 \mathrm{kDa} \mathrm{Mr}$ (Figure 2B). However, regardless of the $\mathrm{Mr}$ and $\mathrm{pI}$ range, the phenol-based protocols showed better separation. The phenol with methanol/ammonium protocol showed the highest resolution (Figure 2A, B, and C).

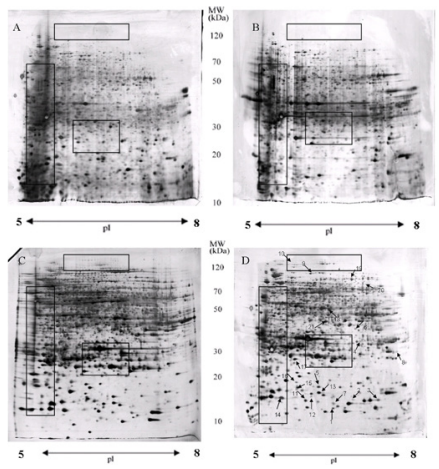

Figure 1. Comparison of 2-DE patterns for mango peels proteins extracted with four methods. A. 2-D clean-up kit. B. TCA/acetone precipitation. C. Phenol extraction. D. Phenol extraction with methanol/ammonium acetate precipitation. Extracted proteins $(190 \mu \mathrm{g})$ were separated on $17 \mathrm{~cm}$ IPG strips, $\mathrm{pH} 5-8$ in the IEF, followed by $12 \%$ SDS-PAGE, and stained with silver Arrows show the spots identified by mass spectrometry.

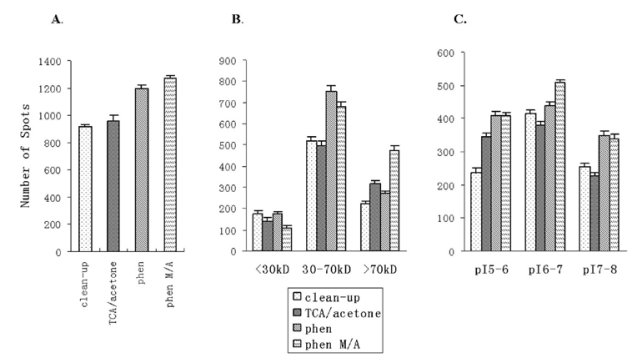

Figure 2. Spot numbers for proteins detected from the four methods. A. The total number of spots. B. The number of spots with different categories of molecular weight. C. The number of spots with different categories of $\mathrm{pI}$. Clean-up: 2-D clean-up kit treatment. TCA/acetone: TCA/acetone precipitation. Phen M/A: Phenol with methanol/ ammonium acetate precipitation. Phen: phenol extraction method.

Genetics and Molecular Research 15 (3): gmr.15039006 


\section{Protein spots identification}

To validate the protein separation, 21 spots were randomly selected for further compatibility study with mass spectrometry. These protein spots included acidic and basic, high and low molecular weight, and abundant and low abundant proteins in the gel produced from the phenol with methanol/ammonium acetate protocol (Figure 1D). Sixteen spots successfully identified by database searching are involved in immunity and defense, oxidation and reduction, and amino acid and carbohydrate metabolism, whereas five spots were not identified (Table 1). Among all the spots, seven proteins $(2,5,7,11,12,13$, and 14) were identified to be heat shock proteins with low molecular weights between 10 to 17 $\mathrm{kDa}$, differing in isoelectric points. Heat shock proteins are part of a stress-related category and play an important role in cell activities, including stabilizing protein folding, preventing refolding of denatured proteins and regulating many signal transduction pathways (Muccilli et al., 2009). Four spots $(1,9,10$, and 15) were unnamed, and predicted proteins could be derived by comparing sequence homology with proteins of other species in the conserved domain database (CDD) of NCBI for their probable functions. The MS and MS/MS spectrograms were obtained for protein identification.

\section{DISCUSSION}

Four protein extraction methods - 2-D clean-up kit, TCA/acetone, phenol extraction and phenol with methanol/ammonium precipitation - have been widely used for extracting proteins from plant materials, among which TCA/acetone and phenol-based methods are the most popular. A successful proteomic analysis of specific species-derived samples, such as mango peel, requires selection and optimization of a suitable protein extraction method. Among these four methods, the commercial 2-D clean-up kit and TCA/acetone methods were less time consuming and easier to perform. In this study, they showed fewer total detected spots compared to the other two methods, whereas both yielded a similar number of protein spots and displayed sharper spot definition in the range of 10-30 kDa, which tends to lose larger moieties ( $>70 \mathrm{kDa})$. The gel patterns indicated non-protein compounds were co-extracted with the proteins, resulting in smears and streaks in the acidic gel region with $\mathrm{pH} 5-6$. The kit and TCA/acetone precipitation are intended to remove the alkaline proteins, such as ribosomal proteins, and minimize protein degradation (Görg et al., 2004). However, some interfering compounds, such as carbohydrates and polyphenols were not eliminated by the protocols, generating charge heterogeneity and streaking (Carpentier et al., 2005; Jellouli et al., 2010). In addition, the drawback of these methods is that following precipitation, dissolving the proteins can become difficult, which leads to the low protein yield (Chen and Harmon, 2006; Jellouli et al., 2010).

Phenol-based methods are widely applied to protein extraction from the plants and have demonstrated a high clean-up capacity (Chokchaichamnankit et al., 2009; Koay and Gam, 2011). It is a way to avoid the extraction of polysaccharides, lipids, and other nonprotein components. The gel patterns showed that phenol-based extraction methods were most efficient in removing interfering substances and led to the higher quality images. The phenol with methanol/ammonium method produced the best quality protein extraction and separation. The acidic proteins had better resolution with fewer horizontal and vertical streaks. More protein spots in the range of $30-70 \mathrm{kDa}$ and $>70 \mathrm{kDa}$ were found. As is well known, most functional proteins, such as enzymes, are around or over $100 \mathrm{kDa}$.

Genetics and Molecular Research 15 (3): gmr.15039006 


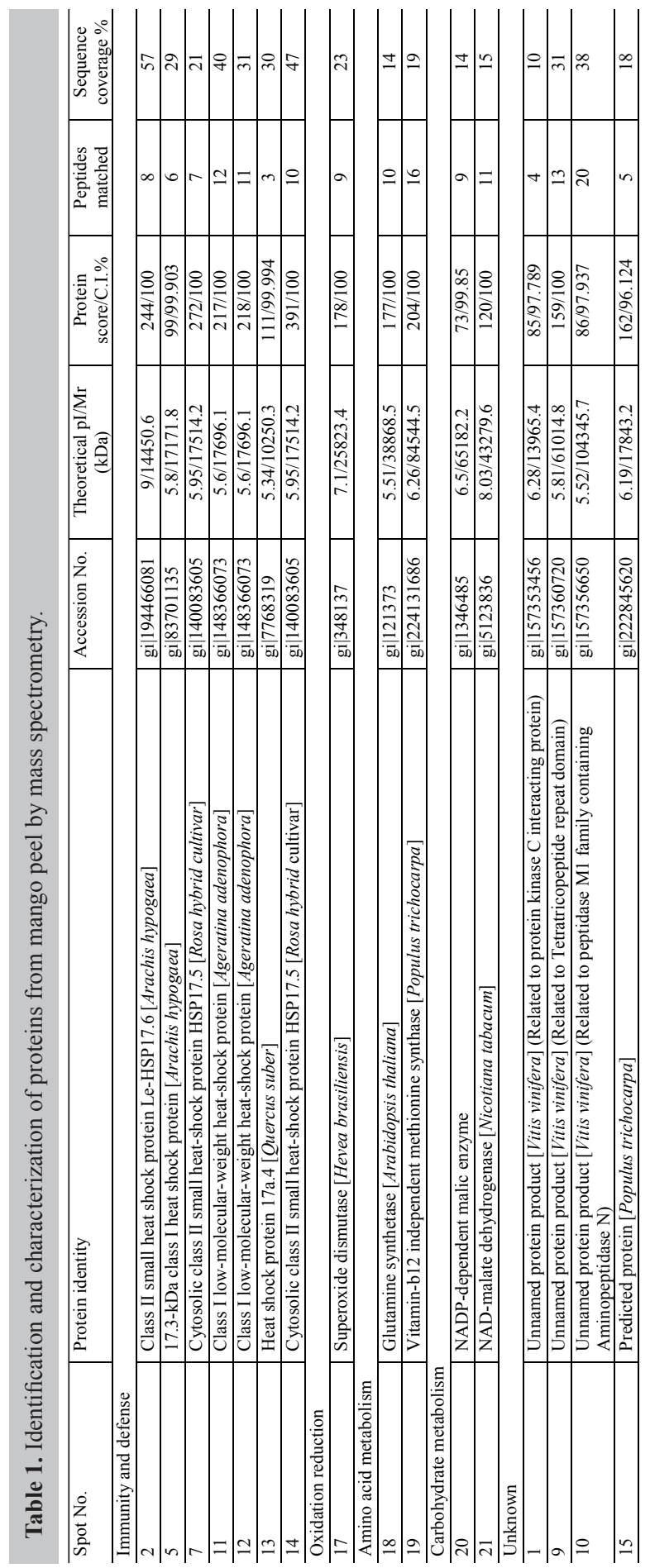

Genetics and Molecular Research 15 (3): gmr.15039006 
Some proteins below $30 \mathrm{kDa}$ may be related to degradation of large functional molecules caused by the slightly longer process of extraction. Compared to the 2-D cleanup kit and TCA/acetone method, the phenol-based protocols showed better resolution with fewer smears and streaks, and got a clearer background. In this study, the number of spots detected on the methanol/ammonium gel was almost $12 \%$ higher than for the 2-D cleanup kit, a non- phenol-based method. More proteins with less acidic $\mathrm{pI}$ and higher $\mathrm{Mr}$ were captured by phenol-based protocols than the 2-D clean-up kit and TCA/acetone procedures, which suggests that lager numbers of high $\mathrm{Mr}$ protein spots for the more neutral and basic gel region can be achieved. However, both phenol extractions would result in the loss of some low molecular weight proteins. Five spots were unidentified in the study, which may have been related to a limited plant proteomic resource, in particular the lack of a mango genome and proteome sequence database. This highlights the necessity to establish a database for this plant. However, the silver staining can detect a protein spot as low as $1 \mathrm{ng}$ (Jellouli et al., 2010), and such low abundance proteins would be difficult to successfully identify.

From the 2-DE results, the four protein extraction methods could be applied for mango peel proteomics. In particular, the phenol with methanol/ammonium precipitation was the most suitable method in this study. The proteins identified by mass spectrometry showed that the method was compatible with the 2-DE. This report provides a valuable and efficient selection of protocols not only for mango peel, but also for other plant species.

\section{ACKNOWLEDGMENTS}

Disease.

Research supported by the free program of The State Key Laboratory of Respiratory

\section{REFERENCES}

Ajila CM, Bhat SG and Prasada Rao UJS (2007). Valuable components of raw and ripe peels from two Indian mango varieties. Food Chem. 102: 1006-1011 http://dx.doi.org/10.1016/j.foodchem.2006.06.036.

Al-Obaidi JR, Mohd-Yusuf Y, Razali N, Jayapalan JJ, et al. (2014). Identification of proteins of altered abundance in oil palm infected with Ganoderma boninense. Int. J. Mol. Sci. 15: 5175-5192 http://dx.doi.org/10.3390/ijms15035175.

Ashoub A, Berberich T, Beckhaus T and Brüggemann W (2011). A competent extraction method of plant proteins for 2-D gel electrophoresis. Electrophoresis 32: 2975-2978 http://dx.doi.org/10.1002/elps.201100150.

Berardini N, Fezer R, Conrad J, Beifuss U, et al. (2005). Screening of mango (Mangifera indica L.) cultivars for their contents of flavonol $O$ - and xanthone $C$-glycosides, anthocyanins, and pectin. $J$. Agric. Food Chem. 53: 1563-1570 http://dx.doi.org/10.1021/jf0484069.

Carpentier SC, Witters E, Laukens K, Deckers P, et al. (2005). Preparation of protein extracts from recalcitrant plant tissues: an evaluation of different methods for two-dimensional gel electrophoresis analysis. Proteomics 5: 2497$2507 \mathrm{http}: / / \mathrm{dx}$.doi.org/10.1002/pmic.200401222.

Cascardo JCM, Buzeli RAA, Almeida RS, Otoni WC, et al. (2001). Differential expression of the soybean BiP gene family. Plant Sci. 160: 273-281 http://dx.doi.org/10.1016/S0168-9452(00)00384-8.

Chen S and Harmon AC (2006). Advances in plant proteomics. Proteomics 6: 5504-5516 http://dx.doi.org/10.1002/ pmic. 200600143 .

Chokchaichamnankit D, Subhasitanont P, Paricharttanakul NM, Sangvanich P, et al. (2009). Proteomic alteration during dormant period of Curcuma Longa rhizomes. J. Proteomics Bioinform. 2: 382-395 http://dx.doi.org/10.4172/ jpb. 1000098 .

Görg A, Weiss W and Dunn MJ (2004). Current two-dimensional electrophoresis technology for proteomics. Proteomics 4: 3665-3685 http://dx.doi.org/10.1002/pmic.200401031.

Hirano H, Islam N and Kawasaki H (2004). Technical aspects of functional proteomics in plants. Phytochemistry 65: 1487-1498 http://dx.doi.org/10.1016/j.phytochem.2004.05.019.

Genetics and Molecular Research 15 (3): gmr.15039006 
Jellouli N, Salem AB, Ghorbel A and Jouira HB (2010). Evaluation of protein extraction methods for Vitis vinifera leaf and root proteome analysis by two-dimensional electrophoresis. J. Integr. Plant Biol. 52: 933-940 http://dx.doi. org/10.1111/j.1744-7909.2010.00973.x.

Kim JG, Park D, Kim BC, Cho SW, et al. (2008). Predicting the interactome of Xanthomonas oryzae pathovar oryzae for target selection and DB service. BMC Bioinformatics 9: 41 http://dx.doi.org/10.1186/1471-2105-9-41.

Koay SY and Gam LH (2011). Method development for analysis of proteins extracted from the leaves of Orthosiphon aristatus. J. Chromatogr. B Analyt. Technol. Biomed. Life Sci. 879: 2179-2183 http://dx.doi.org/10.1016/j. jchromb.2011.05.041.

Lima NB, Marques MW and Michereff SJ (2013). First report of mango anthracnose caused by Colletotrichum Karstii in Brazil. Plant Dis. 97: 1248-1248 http://dx.doi.org/10.1094/PDIS-01-13-0002-PDN.

Méchin V, Damerval C and Zivy M (2007). Total protein extraction with TCA-acetone. Methods Mol. Biol. 355: 1-8 10.1385/1-59745-227-0:1.

Muccilli V, Licciardello C, Fontanini D, Russo MP, et al. (2009). Proteome analysis of Citrus sinensis L. (Osbeck) flesh at ripening time. J. Proteomics 73: 134-152 http://dx.doi.org/10.1016/j.jprot.2009.09.005.

Natarajan S, Xu C, Caperna TJ and Garrett WM(2005). Comparison of protein solubilization methods suitable for proteomic analysis of soybean seed proteins. Anal. Biochem. 342: 214-220 http://dx.doi.org/10.1016/j.ab.2005.04.046.

Rose JKC, Bashir S, Giovannoni JJ, Jahn MM, et al. (2004). Tackling the plant proteome: practical approaches, hurdles and experimental tools. Plant J. 39: 715-733 http://dx.doi.org/10.1111/j.1365-313X.2004.02182.x.

Schieber A, Berardini N and Carle R (2003). Identification of flavonol and xanthone glycosides from mango (Mangifera indica L. Cv. "Tommy Atkins") peels by high-performance liquid chromatography-electrospray ionization mass spectrometry. J. Agric. Food Chem. 51: 5006-5011 http://dx.doi.org/10.1021/jf030218f.

Tanaka N, Matsuoka M, Kitano H, Asano T, et al. (2006). gidl, a gibberellin-insensitive dwarf mutant, shows altered regulation of probenazole-inducible protein (PBZ1) in response to cold stress and pathogen attack. Plant Cell Environ. 29: 619-631 http://dx.doi.org/10.1111/j.1365-3040.2005.01441.x.

Wang W, Tai F and Chen S (2008). Optimizing protein extraction from plant tissues for enhanced proteomics analysis. $J$. Sep. Sci. 31: 2032-2039 http://dx.doi.org/10.1002/jssc.200800087.

Wang Y, Cheung YH, Yang Z, Chiu JF, et al. (2006). Proteomic approach to study the cytotoxicity of dioscin (saponin). Proteomics 6: 2422-2432 http://dx.doi.org/10.1002/pmic.200500595.

Xu C, Sibicky T and Huang B (2010). Protein profile analysis of salt-responsive proteins in leaves and roots in two cultivars of creeping bentgrass differing in salinity tolerance. Plant Cell Rep. 29: 595-615 http://dx.doi.org/10.1007/ $\underline{\mathrm{s} 00299-010-0847-3}$.

Genetics and Molecular Research 15 (3): gmr.15039006 